\title{
FAMILY DEVELOPMENT TOWARD INDEPENDENT FAMILY PLANNING “KAMPUNG” AND TRANSFER OF TECHNOLOGY
}

\author{
Rina Sri Widayati'), Dewi Kartikasari'), Jani Kusanti²) \\ ${ }^{1)}$ School of Health Sciences Aisyiyah, Surakarta, Central Java \\ 2)Universitas Surakarta, Central Java
}

\begin{abstract}
Background: Family planning "kampung" is a program to improve the quality of life of people at the village level through the Family Planning and Family Development program and other sector development programs to create quality small families. This study aimed to investigate the family development toward independent family planning "kampung" and transfer of technology.

Subjects and Method: This was a qualitative study conducted in Pucangsawit, Surakarta, Central Java from Mei to Juli 2019. The theme of this study was family development toward independent family planning "kampung" and transfer of technology. Several key informants were selected for this study. Data were obatained by indepth interview and questionnaire. The data were analyzed descriptively.

Results: Small group family planning counseling training began with material exposure activities, thematic atmosphere development, KB puzzles, and simulations. Cadres' ability to do counseling helped improve knowledge and behavior of family planning acceptors. Creative educational games such as snake and ladder game, quiz, and song helped the elderly family to develop. Gymnastics balance can overcome the balance disorder in the elderly. Kampung KB website, online-based data home conversion, promotion of Pucangsawit community creation, are a new innovation.

Conclusion: Family development toward independent family planning "kampung" and transfer of technology can improve knowledge, behavior, and be sensitive to technology.
\end{abstract}

Keywords: family development, family planning, vocational, technology

\section{Correspondence:}

Rina Sri Widayati. School of Health Sciences Aisyiyah, Surakarta, Central Java. Email: rinasriwidayati@gmail.com. Mobile: 081329638362. 